\author{
Piotr Filipkowski \\ Dobrochna Kałwa
}

\title{
Polifonia historii mówionej
}

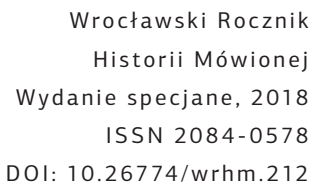

Polska historia mówiona - by roboczo posłużyć się taką zbiorczą kategorią - chociaż tak niedawno przecież (samo)rozpoznana, ma już wyraźne kontury instytucjonalne i widoczny dorobek. Tworzą go liczne projekty dokumentacyjne i badawcze, archiwa gromadzące, opracowujące i udostępniające tysiące nagrań, prace naukowe, wykorzystujące te źródła, oraz publikacje zawierające ich zredagowane wybory, zajęcia akademickie, seminaria i warsztaty edukacyjne, obchodzące wkrótce dziesięciolecie swej działalności Polskie Towarzystwo Historii Mówionej czy niewiele młodszy „Wrocławski Rocznik Historii Mówionej”.

Ważniejsze od tego zgrubnego wyliczenia jest otwarte środowisko ludzi, którzy tworzą w Polsce historię mówioną w jej różnych wariantach praktycznych, teoretycznych i instytucjonalnych. W tym środowisku - dosyć już wyrazistym, choć ciągle, mamy wrażenie (a także porównanie z bardziej okrzepłymi inicjatywami zagranicznymi), bardzo świeżym i intelektualnie żywym - toczą się ważne rozmowy na temat historii mówionej. Dotyczą one zarówno spraw zupełnie praktycznych, a nawet technicznych, jak i bardzo aktualnych problemów etycznych czy prawnych, jak również czysto „akademickich” rozważań metodologicznych i teoretycznych. Nie brakuje w tym dyskursie głosów krytycznych o stanie polskiej historii mówionej, jej deficytach empirycznych (czego nie badamy, a powinniśmy?), 
metodologicznych (jak najlepiej to robić?) i teoretycznych (co z tego ma wynikać poza samym - problematycznym zresztą - przedstawieniem?), wreszcie - o praktycznym jej wykorzystaniu (gdzie i jak używać historii mówionej?). Ponadto w wielu polskich tekstach przynależnych do nurtu historii mówionej widać nie tylko rytualne, lecz i autentyczne intelektualne zmagania z fundamentalnymi dylematami historii mówionej jako takiej. Choć te ostatnie obecne są też w międzynarodowej debacie, stanowiąc nieodłączny element oral history, to bywają u nas konkretyzowane oryginalnymi odniesieniami do dorobku polskiej humanistyki, a przede wszystkim umocowaniem we własnych doświadczeniach badawczych autorek i autorów tych tekstów (referatów konferencyjnych, wypowiedzi seminaryjnych, dyskusji panelowych i publicznych wykładów z jednej strony, z drugiej zaś głosów „kuluarowych” czy zwykłych koleżeńskich rozmów).

Jeśli ta pozytywna diagnoza, tchnąca optymizmem i nadzieją na przyszłość, jest zasadniczo trafna, to tym bardziej decyzja o publikacji wyboru zagranicznych, a ściślej „zachodnich” tekstów dotyczących oral history w polskim tłumaczeniu, wymaga uzasadnienia. Po co nam bowiem taka antologia przekładów, skoro i bez niej nie najgorzej już sobie radzimy? Po co wracać do kanonicznych tekstów, z których wiele jest już historycznym dziedzictwem światowej/globalnej historii mówionej, znanym także w polskim środowisku, które w swoich pionierskich czasach szukało inspiracji i legitymizacji w literaturze zagranicznej?

W naszym przekonaniu antologia tekstów ma być przede wszystkim zaproszeniem coraz szerszego grona polskich praktyków historii mówionej do metodologicznego i teoretycznego namysłu nad jej naturą i do dyskusji o niej. Nie jest bowiem tak, że wszyscy mają swobodny dostęp do zagranicznej literatury akademickiej dotyczącej oral history. Ani nie jest tak, że język oryginału, nawet gdy jest to angielski, nie stanowi żadnej bariery w tym dostępie. Jesteśmy więc przekonani, że możliwość skorzystania z kompetentnego polskiego przekładu, znajdującego się w wolnym dostępie, a jednocześnie mającego postać artykułu opublikowanego w znanym i uznanym piśmie naukowym, jakim jest „Wrocławski Rocznik Historii Mówionej”, zasadniczo zmienia kontekst ich odbioru. Nie tylko go demokratyzuje „ilościowo”, poszerzając grono potencjalnych odbiorców, lecz także, by tak rzec, „jakościowo”. Pozwala bowiem wszystkim polskim czytelniczkom i czytelnikom, na dużo bardziej wnikliwą, bardziej uważną i dokładniejszą lekturę, a co za tym idzie, na pełniejsze zrozumienie tych tekstów, a potem na ich lepsze wykorzystanie - czy to we własnej praktyce badawczej, czy w zajęciach dydaktycznych, 
czy na inne jeszcze sposoby. Polskie tłumaczenia są ponadto elementem trwającego od lat procesu wypracowywania wspólnego języka i terminologii, wykuwających się podczas spotkania wiedzy lokalnej z globalną. Pracując w obszarze historii mówionej, dobrze wiemy, jak ważny jest język - i ten mówiony, i ten pisany. Wiemy też, że nawet biegła znajomość obcych języków nie znosi różnicy między słuchaniem i czytaniem w języku własnym a podobnymi (tylko podobnymi) praktykami w języku obcym. Oczywiście w przekładzie coś się także traci - ale w tym wypadku znacznie więcej zyskuje.

Dydaktyka - zarówno akademicka, jak i szkolna czy pozaszkolna - uzasadnia wagę tej antologii tłumaczeń w szczególny sposób. Wielu z nas uczestniczyło lub uczestniczy w rozmaitych działaniach edukacyjnych. Niektórzy z nas prowadzili i prowadzą zajęcia, lekcje i warsztaty, inni w przyszłości może również będą to robić. Dostępność polskich tłumaczeń tekstów uznanych w danej dyscyplinie za klasyczne jest niezbędnym elementem dbania o jakość tych różnych form edukacji. Nie ma wątpliwości, że znacznie więcej osób zapozna się ze światowym dorobkiem historii mówionej, jeśli będzie on choć w części dostępny po polsku. W dobie coraz powszechniejszego „nieczytania”, operowania fragmentaryczną wiedzą zasłyszaną i „obejrzaną”, cytowaną wybiórczo z drugiej ręki - niestety także w instytucjach edukacyjnych wszystkich szczebli - taka antologia czyni zasadniczą, choć oczywiście potencjalną, różnicę. I w tym kontekście jest bowiem istotne, że te teksty zebrane są w jednym miejscu, uporządkowane, udostępnione w przejrzystym i przystępnym formacie - a nie tylko „krążą w Internecie”, jak wiele anglojęzycznych tekstów dotyczących (nie tylko) oral history. Taki sposób ich wyodrębnienia i „podania” zmienia przecież sytuację odbioru ich treści. Wskazuje, że jest ktoś, kto te teksty proponuje - autorzy wyboru i redaktorzy pisma naukowego, ale też, w szerszym planie wykraczającym poza polskich oralistów, środowisko osób identyfikujących się, także w sporze, z praktyką, metodologią i teorią historii mówionej. Taka polskojęzyczna antologia, choć przybliża teksty „obce”, mocniej zarysowuje również nasze własne kontury instytucjonalne - przynajmniej widziane z zewnątrz. Sygnalizuje bowiem, że potrzebujemy wygodnego, podręcznego dostępu do ważnych tekstów „zachodniej” oral history - na własny praktyczny użytek i we własnym języku. Ma być nie tylko zestawem kanonicznej wiedzy i legitymizacją podejmowanych przez nas badań i refleksji, lecz także inspiracją do krytycznego namysłu w poszukiwaniu odpowiedzi na pytanie o lokalną tożsamość polskiej historii mówionej i jej miejsce na globalnej mapie oral history. 
Nie mając wątpliwości, że antologia - być może pierwsza z wielu - jest potrzebna i użyteczna, zaczęliśmy się zastanawiać, jakich tekstów szczególnie potrzebujemy. Na pewno zróżnicowanych, bo taka przecież - właśnie polifoniczna - jest współczesna światowa oral history. I to zarówno autorsko - ze względu na doświadczenie badawcze i, a może przede wszystkim, temperament intelektualny i literacki styl wypowiedzi; tematycznie - ze względu na przedmiot badań; teoretycznie - ze względu na intelektualne tradycje, do jakich sięgają autorzy; jak i historycznie - ze względu na czas i miejsce powstania tych artykułów. Zaproponowany tutaj skromny wybór nie może, to oczywiste, pokazać całego zróżnicowania oral history, nie może również stanowić jego reprezentatywnej próby. Dokonując go, kierowaliśmy się innym zamiarem - chcieliśmy jednocześnie zaproponować teksty, które stale powracają w aktualnych dyskusjach o praktyce, metodologii i teorii oral history, podobnie jak powracają nazwiska ich autorów, także w dyskusjach toczonych w Polsce. Te odwołania nie są przypadkowe ani jedynie rytualne, lecz bywają, jak już powiedzieliśmy, intelektualnie żywe. Wierzymy, że dostępność tych tekstów w języku polskim będzie zachętą do włączenia się w te dyskusje nowych uczestników, którzy spojrzą na nie w nowy sposób i ożywią je, wprowadzając do nich nowe konteksty. Chcieliśmy też, by ten niewielki przecież wybór dotyczył spraw rzeczywiście istotnych dla polskiej praktyki i teorii historii mówionej. Takimi z pewnością są ciągle kwestie definicyjne. Czym jest, czym powinna, a czym może być historia mówiona w kontekście całej „reszty” historiografii (o ile w ogóle uznamy, że jej miejsce znajduje się w ramach nauk historycznych)? Jak ją usytuować wobec praktyk badawczych innych dyscyplin humanistycznych (kulturoznawstwa, etnolingwistyki, etnologii) oraz nauk społecznych (zwłaszcza socjologii, antropologii i pedagogiki)? Nie są to tylko teoretyczne dywagacje, bo to od nich zależy, czy będziemy szukać (i znajdywać!) w historiach mówionych informacji o wydarzeniach i faktach historycznych, indywidualnych i zbiorowych przeszłych doświadczeń, czy raczej ich interpretacji, zapisów pamięci o nich, sposobów ich wysłowienia i narracyjnego uporządkowania. I czy wyniki tych poszukiwań rzutować będą na wyobrażoną historyczną przeszłość czy na teraźniejszą, zbiorową i kulturową o niej pamięć.

Powyższe pytania - nienowe dla namysłu nad badaniem przeszłości i pisaniem (o) historii - zyskały szczególną wyrazistość i rangę wraz z językowym, czy szerzej, kulturowym zwrotem we współczesnej humanistyce. Historycy zostali wówczas zwolnieni z zadania, jakim było rekonstruowanie 
prawdziwego przebiegu zdarzeń, ustalania, jak było naprawdę (to, że nie wszyscy i nie wszędzie poczuli się zwolnieni z tych zadań, to oddzielna kwestia). Ich uwaga zwróciła się również w kierunku pytania o język opisu wydarzeń oraz o rolę historyka jako konstruktora opowieści o przeszłości, podporządkowanego regułom własnej kultury. Ów zwrot miał kluczowy wpływ na teoretyczną i metodologiczną refleksję o historii mówionej, co jest zresztą zupełnie zrozumiałe, zważywszy na jej ontologiczną i epistemologiczną niejednoznaczność, transdyscyplinarną tożsamość i otwartość. Nadał tej refleksji rozmach, pokazując, że oral history to nie tylko sposób na poszerzenie bazy źródłowej badań historycznych i uzyskanie dostępu do informacji o charakterze faktograficznym. To także miejsce, w którym ogniskują się najważniejsze problemy współczesnej humanistyki i nauk społecznych. Teksty z części pierwszej naszego wyboru powstały w czasie tego zwrotu i są świadectwem intelektualnego ożywienia i odnowienia historii mówionej. I nie jest to tylko świadectwo historyczne, ale aktualne źródło inspiracji. Bo choć od ich napisania minęło w większości wypadków już kilkadziesiąt lat, a humanistyka przeszła przez ten czas całą serię kolejnych zwrotów (albo raczej wpadła w stan permanentnej zwrotności), to poruszone wtedy problemy pozostają dla historii mówionej wciąż fundamentalne. Nic dziwnego więc, że są przedmiotem refleksji polskich oralistów, stanowiąc w dalszym ciągu inspirację do fundamentalnych dla środowiska dyskusji i poszukiwań własnej tożsamości. Wydają się nam istotne także z tego względu, że samo doświadczenie prowadzenia wywiadu jest szczególnie problematyczne dla historyków, gdyż sytuacja współautorstwa źródła historycznego jest dla nich sytuacją nową i niezwykłą. W pewnym sensie sytuacją nawet sprzeczną z zasadami ich warsztatu, który daje narzędzia do pracy z materiałem "historycznym”, już istniejącym, zastanym, niewymagającym od historyka - tak wydawało się przez lata - obecności, uczestnictwa w procesie tworzenia i zaangażowania, również emocjonalnego.

Podobnie jak aktualna jest problematyka stojąca za kategoriami świadectwa i świadczenia. Mają one obszerną literaturę we współczesnej humanistyce, która dalece wykracza poza historię (historiografię) czy tak popularne w ostatnich latach badania nad - rozmaicie zresztą definiowaną - pamięcią. Tym bardziej więc poza historię mówioną. Zdecydowaliśmy się jednak zaproponować kilka tekstów, które wprost wpisują praktyki oral history w refleksje o świadczeniu i świadectwie właśnie. Po co jednak takie wyodrębnienie? Są po temu ważne powody. Otóż tylko część powojennej oral history (czyli po prostu nowoczesnej, samoświadomej historii 
mówionej) wpisuje się w dość znaną, wielokrotnie przywoływaną w tekstach, opowieść o rozwoju tej metody i praktyki badawczej, znaczonej nazwiskami Allana Nevinsa - założyciela w 1948 r. Columbia University Oral History Research Office, Ronalda Grele'a - kolejnego dyrektora Biura, Paula Thompsona, którego książka The Voice of the Past. Oral History z 1978 r. ugruntowała metodę historii mówionej w obszarze historii społecznej, a potem - po zwrocie kulturowym i pamięciowym - nazwiskami Michaela Frischa, Alessandro Portellego, Luisy Passerini i wielu innych. Istnieje bowiem drugi, bardzo wyrazisty nurt oral history, który z tamtym - z punktu widzenia historii histografii zapewne głównym - nigdy nie został zintegrowany, a nieraz w ogóle wypada z pola jego widzenia.

Chodzi o Holokaustową historię mówioną, za której początek uznać można niezwykłe przedsięwzięcie dokumentacyjne Davida Bodera, a za punkt kulminacyjny - spektakularny projekt Visual History Foundation zrealizowany w połowie lat 9o. ubiegłego wieku, którego efektem jest archiwum liczące dziś ponad 50 tys. świadectw wideo ocalałych i świadków Zagłady, dostępne wirtualnie z wielu miejsc na świecie (w Polsce z Muzeum Historii Żydów Polskich Polin). Choć zaproponowana tu nazwa i przywołane przykłady wskazują na doświadczenie Zagłady, to oral history spod znaku świadectwa nie ogranicza się do indywidualnych zapisów tego doświadczenia (czy konstelacji doświadczeń, które - po czasie - zyskały zbiorczą nazwę „Zagłady”). Ma ono tu charakter bardziej paradygmatyczny niż historyczny. Żadne inne współczesne, zbiorowe doświadczenie historyczne nie postawiło bowiem równie ostro problemu konieczności - i zarazem niemożności - świadczenia i świadectwa. Wyodrębniamy więc te kilka tekstów, prawdopodobnie mniej znanych, niż te z pierwszej części naszego wyboru, nie dlatego, że wyjątkowość Zagłady wymaga osobnego instrumentarium teoretycznego i metodologicznego, także w obrębie oral history. Raczej po to, by pokazać możliwość spojrzenia na źródła historii mówionej z innej nieco perspektywy. W szczególności na źródła, które są świadectwami doświadczeń skrajnych, ekstremalnych, granicznych - zagładowych, obozowych, łagiernych, frontowych itp. Niemała część wschodnioeuropejskiej, w tym polskiej, historii mówionej, jaką dotąd praktykowano, takich doświadczeń przecież dotyczy i o takich doświadczeniach próbuje zaświadczać. Stawki etyczne i poznawcze takiej oral history bywają inne, niż tej z głównego historiograficznego nurtu. Mamy więc nadzieję, że teksty z tej części w szczególny sposób sprzyjać będą (re)interpretacjom własnej pracy dokumentacyjnej i badawczej polskich oralistów i staną się 
zaproszeniem - także dla innych - do twórczych, w tym krytycznych, odczytań zgromadzonego przez nich w ostatnich latach „materiału źródłowego”. Temu ostatniemu celowi służyć mogą zresztą z powodzeniem wszystkie proponowane tu teksty.

Niniejszy wybór przekładów klasycznych tekstów oral history na język polski jest z pewnością najobszerniejszy i - mimo wszystkich poczynionych wyżej zastrzeżeń - najbardziej kompletny. Przy całym zróżnicowaniu poszczególnych tekstów, stanowi on bowiem pewną całość, którą traktować można jako polifoniczną, a zarazem dość zwartą propozycję teoretyczną i metodologiczną w obrębie historii mówionej - jeśli nie ze względu na udzielane w nich odpowiedzi, to z pewnością na zestaw stawianych przez nie pytań. Tym istotniejsze jest wskazanie, że dysponujemy już kilkoma tekstami zagranicznymi w języku polskim, które, chociaż pojawiły się wcześniej, poszerzają i uzupełniają niniejszy wybór. W szczególności mamy na myśli artykuły Paula Thompsona, Głos przeszłości. Historia mówiona, oraz Michaela Frischa, Historia mówiona i rewolucja digitalna. W kierunku postdokumentalnej wrażliwości - oba opublikowane w książce Teoria wiedzy o przeszłości na tle wspótczesnej humanistyki, pod redakcją Ewy Domańskiej; teksty Lutza Niethammera, Po tej stronie floating gap. Pamięć zbiorowa i konstrukcja tożsamości $w$ dyskursie naukowym, oraz Luisy Passerini, Shareable Narratives? Intersubiektywność, historie życia i reinterpretowanie przeszłości - oba wydane w tomie (Kon)teksty pamięci. Antologia, pod redakcją Kornelii Kończal'² wreszcie teksty Alexandra von Plato, Historia a psychologia - historia mówiona a psychoanaliza. Zarys problemu i przeglad literatury, i Franki Maubach, Świadekhistorii. Swobodne wspominanie a krytyka źródła historycznego - o ambiwalencji metody w zachodnioniemieckiej oral history okoto roku 1980 - oba opublikowane

P. Thompson, Głos przeszłości. Historia mówiona, [w:] Teoria wiedzy o przeszłości na tle wspótczesnej humanistyki, red. E. Domańska, s. 281-294; M. Frisch, Historia mówiona i rewolucja digitalna. W kierunku postdokumentalnej wrażliwości, [w:] ibidem, s. 295-318.

L. Niethammer, Po tej stronie floating gap. Pamięć zbiorowa i konstrukcja tożsamości w dyskursie naukowym, [w:] (Kon)teksty pamięci. Antologia, red. K. Kończal, Warszawa 2014, s. 31-51; L. Passerini, Shareable Narratives? Intersubiektywność, historie życia i reinterpretowanie przeszłości, [w:] ibidem, s. 191-203. 
w III tomie „Wrocławskiego Rocznika Historii Mówionej”. Warto sięgać ponownie do tych tekstów, wpisując je w szerszy kontekst refleksji o historii mówionej zakreślony niniejszą antologią.

Zanim zaprosimy do lektury, przybliżmy nieco poszczególne teksty. Antologię otwiera artykuł Co stanowi o odmienności historii mówionej Alessandro Portellego. Spośród licznych i ważnych publikacji tego jednego z najwybitniejszych badaczy i propagatorów historii mówionej na świecie, zdecydowaliśmy się na tekst pochodzący z epoki wielkich debat nad statusem naukowym badań opartych na wątpliwym - zdaniem wielu historyków - materiale. Portelli rozprawia się w tym opracowaniu z wątpliwościami i zarzutami stawianymi nie tylko wówczas, ale i dziś, wszędzie tam, gdzie pojawia się „widmo historii mówionej”. Ów swoisty manifest posiada ogromne walory edukacyjne, ponieważ porządkuje i wyjaśnia fundamentalne dla historii mówionej kwestie natury epistemologicznej i warsztatowej: wiarygodności źródeł mówionych, konsekwencji ich oralności i roli transkrypcji, czy wreszcie obiektywizmu przekazu, by wymienić tylko niektóre $\mathrm{z}$ nich. Prostota i klarowność odpowiedzi przedstawionych w tym tekście jest zwodnicza i pozorna, o czym czytelnicy będą mieli okazję się przekonać wraz z lekturą kolejnych artykułów, stanowiących świadectwo nowych problemów i wątpliwości towarzyszących oralistom w ich praktyce badawczej. To bowiem, co charakterystyczne dla osób parających się oral history, to świadomość potrzeby autorefleksji i namysłu teoretycznego nad efektami podejmowanych działań i znaczeniem wiedzy tworzonej na podstawie wywiadów ze świadkami historii. Jak bardzo skomplikowaną i niejednoznaczną naturę ma wiedza o przeszłości i teraźniejszości płynąca z ustnych opowieści, przypomina tekst Michaela Frischa, w którym analizuje on spektrum możliwych znaczeń wpisywanych w trakcie lektury książek, takich jak stanowiąca punkt wyjścia do rozważań słynna praca Studsa

A. von Plato, Historia a psychologia - historia mówiona a psychoanaliza. Zarys problemu i przeglad literatury, „Wrocławski Rocznik Historii Mówionej”, R. 3 (2013), s. 5-37; F. Maubach, Świadek historii. Swobodne wspominanie a krytyka źródta historycznego - o ambiwalencji metody w zachodnioniemieckiej oral history około roku 1980, ibidem, s. 39-72. Na łamach Rocznika ukazało się już wiele zagranicznych tekstów - także autorstwa badaczy z Europy Środkowej i Wschodniej (m.in.: Gelinady Grinchenko, Miroslava Vanka, Pavla Mücke). Wymieniamy tu jednak tylko te dwa „zachodnie” artykuły, gdyż teoretycznie i metodologicznie są najbliższe niniejszej antologii. 
Terkela, Hard Times: An Oral History of the Great Depression z roku 1970. Koncepcja „więcej historii - żadnej historii”, zaproponowana przez Frischa, pojawia się w kolejnym artykule, Historia mówiona jako materiat dowodowy, w którym Ronald Grele przedstawia etapy rozwoju i główne nurty współtworzące współczesną historię mówioną - od tworzenia archiwów, przez działalność społeczną i edukacyjną, po badania historyczne. Wśród nich na szczególną uwagę zasługują te, wpisujące się w nurt nowej historii społecznej, realizujące postulat zapisania i wydobycia oddolnej perspektywy historycznej. „Egalitarnej” historii mówionej, kierującej swoją uwagę ku klasom ludowym, grupom zmarginalizowanym i wykluczonym z hegemonicznego dyskursu poświęcony jest artykuł Staughtona Lynda, Oddolna historia mówiona. Tekst ten pozostaje w dalszym ciągu aktualny dla polskich badań, także ze względu na refleksję dotyczącą politycznych i społecznych wymiarów działalności naukowej, jak również, traktowanej z rezerwą, jeśli nie z podejrzliwością, postawy osobistego zaangażowania. Tymczasem nie sposób uniknąć takiego zaangażowania w sytuacji, gdy badacz uczestniczy w tworzeniu źródła historycznego, którego treść i forma uzależniona jest od interakcji osób uczestniczących w rozmowie. Wywiadowi rozumianemu jako performatywny akt komunikacji między „badaczem” i „badanym”, albo inaczej, „słuchaczem” i „rozmówcą”, poświęcony jest artykuł Evy M. McMahan, który pozwala poszerzyć spektrum interpretacji wywiadu.

Artykuł Paula R. Thompsona, Pamięć i tożsamość, stanowiący swoisty pomost między częściami antologii, poświęcony jest najtrudniejszemu bodaj, terapeutycznemu wymiarowi historii mówionej, która stawia przed badaczami wymóg empatycznego zrozumienia. Wywiad - podobnie jak sesja psychoanalityczna - stwarza rozmówcom/świadkom historii szansę przypomnienia sobie tego, co wyparte, ujęcia w narrację tego, co niepojęte i graniczne, a przez to odzyskania tego, co utracone - wspomnień kształtujących tożsamość i poczucie sensu własnego życia.

Tekst Aleidy Assmann, otwierający drugą część antologii, to erudycyjny, a zarazem przystępny esej kulturoznawczy, rekonstruujący historyczno-kulturowe odmiany składania świadectwa, które doprowadziły do krystalizacji różnych figur świadka i typów świadectw. W tak uporządkowanym polu znacznie łatwiej zobaczyć i zrozumieć specyfikę oral history - tej „zwykłej” i tej „Holokaustowej” (albo emfatycznej, jak to określiła niemiecka 
18 badaczka Dorothe Wierling ${ }^{4}$ ) - na tle świadectw sądowych z jednej, i religijnych z drugiej strony. Tekst Assmann daje się czytać na wiele sposobów - także jako kulturologiczne studium źródłoznawcze.

Z kolei esej Luisy Passerini Pamięci. Pomiędzy milczeniem a zapomnieniem, poświęcony jest kwestii istotnej dla zrozumienia kształtowania pamięci zbiorowych w XX w., a mianowicie mechanizmom tworzącym obszary „zbiorowego zapomnienia” oraz działaniom przywracania tego, co z pamięci zostało usunięte, przemilczane, pominięte lub wyparte. Przywołane w erudycyjnym szkicu badania i teksty wychodzą daleko poza granice pamięci europejskich, dając tym samym ogląd zjawisk pamięci i milczenia w ich globalnym wymiarze. Tym samym autorka zachęca nas do porzucenia aroganckiego przekonania o naszej unikatowości i kulturowej wyższości.

Tony Kushner w swoim tekście nie tylko przystępnie szkicuje historię Holokaustowej historii mówionej, której owocem są największe w świecie archiwa wywiadów - świadectw historii mówionej. Autor stawia tym źródłom ważne pytania teoretyczne i metodologiczne, zachęcając, by wydobywać je z archiwalnego niebytu i spisać nieklasyczną historiografię Zagłady. Propozycje te z powodzeniem dałoby się rozszerzyć na znaczną część dorobku źródłowego polskiej historii mówionej.

Antologię zamyka interesujące studium Doriego Lauba i Johanny Bodenstab, opisujące badawczy powrót po 25 latach do grupy rozmówców ocalałych z Zagłady, z którymi zarejestrowano wywiady dla Fortunoff Video Archive for Holocaust Testimonies, jednego z najważniejszych archiwów takich świadectw. Autorzy porównują oddzielone ćwierćwieczem narracje tych samych osób, wydobywając i analizując w perspektywie psychologicznej zarówno stabilne wzory biograficznej pamięci i narracji, jak i ich zerwania, nieciągłości i różnice. W efekcie otrzymujemy wnikliwe studium empiryczne, które może być ważnym głosem w dyskusji, toczonej także wśród polskich badaczy i praktyków oral history, nad (nie)stabilnością pamięci i narracji autobiograficznych. Również ten tekst - jak pewnie wszystkie w tym tomie - może rozczarować zarówno tych, którzy chcieliby

D. Wierling, Zeitgeschichte ohne Zeitzeugen. Vom kommunikativen zum kulturellen Gedächtnis - drei Geschichten und zwölf Thesen, „BIOS. Zeitschrift für Biographieforschung, Oral History und Lebensverlaufsanalysen”, T. 21 (2008), nr 1, s. 28-36. Pada tam określenie „Zeitzeugen im emphatischen Sinn”, czyli „świadkowie historii w sensie empatycznym"; ibidem, s. 28. 
zredukować historię mówioną do metody gromadzenia nieznanych faktów historycznych, jak i tych, którzy widzą w niej jedynie indywidualne artykulacje wzorów pamięci zbiorowej i historycznych dyskursów.

Oral history, jaką prezentuje nasz wybór, jest polifoniczna, i nie daje się zamknąć w jednoznaczne schematy teoretyczne i metodologiczne. Uważamy, że to dobrze wróży jej dalszej żywotności. 